\title{
ANALISIS KEMAMPUAN BERPIKIR KREATIF SISWA DALAM MENYELESAIKAN SOAL MATEMATIKA KELAS $X$ TKJ SMK SWASTA HARAPAN
}

Oleh:

\author{
Siti Syahroni ${ }^{1}$, Rahmatika Elindra ${ }^{2}$, Nunik Ardiana ${ }^{3}$ \\ Fakultas Matematika dan Ilmu Pengetahuan Alam Institut Pendidikan Tapanuli Selatan
}

\begin{abstract}
Abstrak
Penelitian ini bertujuan untuk mengetahui kemampuan berpikir kreatif siswa berbasis kemampuan akademik tinggi, sedang dan rendah. Pendekatan penelitian menggunakan kualitatif dan pengumpulan data menggunakan wawancara dan tes, informan yang terdiri dari guru matematika dan 5 siswa (1 siswa berkemampuan akademik tinggi, 2 siswa berkemampuan akademik sedang, dan 2 siswa berkemampuan akademis rendah). Hasil penelitian menunjukkan bahwa siswa yang memiliki kemampuan akademik tinggi memiliki keterampilan berpikir yang lancar, luas, otentik, dan detail, siswa yang memiliki kemampuan akademik rata-rata memiliki keterampilan berpikir yang baik tetapi belum sepenuhnya menguasai langkah-langkah dalam menyelesaikan soal dan kesimpulan dari soal - soal, dan siswa yang memiliki kemampuan akademis rendah cenderung memiliki kemampuan berpikir kurang kreatif dan kurang baik karena tidak mampu memahami masalah, membuat langkah - langkah dalam memecahkan soal, kemampuan berpikir dari pikiran sendiri dan membuat jawaban yang rinci.
\end{abstract}

Kata kunci: kemampuan, berpikir kreatif

Abstract
The aim of this study is to know students' creative thinking based high, average and low academic abilities. The approach of the research used qualitative and interview and test were used in collecting the data, the informant which included mathematics teacher and 5 students ( 1 student had high academic ability, 2 students had average academic, and 2 students had low academic). The results of the research shows student who had high academic had the skills to think fluently, breadth, authenticity, and detail, student who had average academic had good thinking skills but have not fully mastered the steps in solving the questions and conclusions of the questions, and students who had low academic abilities tend to have less creative thinking skills that are not good because they are unable to understand problems, make steps - steps in solving questions, the ability to think from one's own thoughts and make detailed answers.

\section{Keywords: ability, creative thinking}

\section{PENDAHULUAN}

Pendidikan adalah proses interaksi antara guru dengan siswa yang bertujuan untuk meningkatkan perkembangan mental sehingga menjadi mandiri dan utuh. Secara umum dapat dikatakan bahwa pendidikan merupakan satuan tindakan yang memungkinkan terjadinya belajar dan perkembangan. Pendidikan akan selalu memiliki peran penting dalam kehidupan manusia selama manusia hidup karena pendidikan dapat menjadikan manusia bermasyarakat dengan mandiri dalam berbangsa dan bernegara. Dalam mempelajari matematika, berpikir kreatif menjadi pokok penting bagi siswa. Masih banyak sekolah yang mempunyai kemampuan berpikir kreatif siswa masih terbilang rendah. Sebagai contoh siswa merasa kebingungan untuk melakukan pengelompokan unsur yang diketahui dalam soal, kesalahan dalam melakukan operasi matematika, dan menonton terhadap contoh soal yang diberikan oleh gurunya. Pelajaran matematika mengharuskan setiap siswa memiliki kemampuan memahami rumus, berhitung, menganalisis, mengelompokkan objek, membuat alat peraga, membuat model matematika, dan lain-lain.

Dalam mempelajari matematika, berpikir kreatif menjadi pokok penting bagi siswa. Masih banyak sekolah yang mempunyai kemampuan berpikir kreatif siswa masih terbilang rendah. Sebagai contoh siswa merasa kebingungan untuk melakukan pengelompokan unsur yang diketahui dalam soal, kesalahan dalam melakukan operasi matematika, dan menonton terhadap contoh soal 
ISSN. 2621-9832

JURNAL MathEdu (Mathematic Education Journal) http://journal.ipts.ac.id/index.php/MathEdu Vol. 4 No. 3 November 2021

yang diberikan oleh gurunya. Pelajaran matematika mengharuskan setiap siswa memiliki kemampuan memahami rumus, berhitung, menganalisis, mengelompokkan objek, membuat alat peraga, membuat model matematika, dan lain-lain.

Berdasarkan hasil studi pendahuluan yang peneliti lakukan pada hari Senin tanggal 1 Februari 2021 di SMK Swasta Harapan masih banyak siswa yang mengalami kesulitan menjawab soal yang diberikan oleh peneliti, siswa bingung menyelesaikan soal dan menentukan nilai-nilai pada soal karena tidak tau rumus apa yang harus digunakan. siswa belum memahami soal yang diberikan. Sehingga hasil atau jawaban yang diberikan salah walaupun rumus yang digunakan sudah benar.Dapat diketahui bahwa siswa kurang mampu menyelesaikan soal-soal yang berkaitan dengan berpikir kreatif. Kemampuan berpikir kreatif adalah satu kemampuan yang harus dimiliki siswa untuk mencapai tujuan pembelajaran yang baik dan menghasilkan siswa yang kreatif dalam menyelesaikan masalah. Tapi kemampuan berpikir kreatif yang dimiliki siswa di Sekolah tergolong masih rendah. Hal ini dapat dilihat dari hasil penyelesaian soal yang dimiliki siswa saat diberikan soal oleh peneliti. Berdasarkan latar belakang di atas, tentang permasalahan dalam pembelajaran matematika penulis terdorong untuk melakukan penelitian dengan mengangkat judul "Analisis Kemampuan Berpikir Kreatif Siswa Dalam Menyelesaikan Soal Matematika Kelas X TKJ SMK Swasta Harapan".

\section{Hakikat Kemampuan Berpikir Kreatif}

Setiap manusia pasti memiliki kemampuan. Kemampuan yang dimiliki seseorang pasti berbeda dengan yang dimiliki orang lain. Kemampuan merupakan kesanggupan, kecakapan atau kekuatan yang dimiliki seseorang untuk menyelesaikan suatu masalahatau pekerjaan.Kemampuan berasal dari kata "mampu". Dalam kamus besar bahasa indonesia mampu artinya kuasa (bisa, sanggup, melakukan sesuatu, dapat). Sedangkan Kemampuan adalah kesanggupan atau kecakapan yang dimiliki seorang individu dalam menguasai suatu keahlian dan digunakan untuk mengerjakan beragam tugas dalam suatu pekerjaan. Mohammad Zain dalam (SriRejeki, Rahmatika dan Agus 2019) menyatakan "Kemampuan adalah kesanggupan, kecakapan, kekuatan, kita berusaha dengan diri kita sendiri'. Menurut Robin dalam (Nurhalima, Eva dan Muhammad 2014), "Kemampuan adalah kapasitas seorang individu untuk mengerjakan berbagai tugas dalam suatu pekerjaan". Muhibbin dalam (SriRejeki, Rahmatika dan Agus2019) menyatakan "kemampuan adalah hasil belajar yang didapat sebelum mendapat kemampuan yang lebih tinggi". Berdasarkan pendapat para ahli diatas, penulis dapat menyimpulkan bahwa kemampuan adalah usaha seseorang dalam mewujudkan kesanggupan dan kecakapan untuk kekuatan dalam diri seseorang untuk menyelesaikan suatu pekerjaan berhasil dengan baik.

Berpikir merupakan menggunakan akal kita untuk memutuskan atau mempertimbangkan sesuatu. Purwanto dalam (SriRejeki, Rahmatika dan Agus 2010) menyatakan "berpikir merupakan satu keaktifan pribadi manusia yang mengakibatkan penemuan yang terarah kepada suatu tujuan, kita berpikir untuk menemukan pemahaman atau pengertian yang kita kehendaki'”. Menurut Prawironegoro (SriRejeki, Rahmatika dan Agus 2010) menyatakan"berpikir merupakan kerja otak mengolah data inderawi yang menghasilkan pengertian, pernyataan, dan penalaran. Itu artinya bahwa berpikir harus objektif karena data inderawi itu hasil dari kemampuan mental menangkap kondisi objektif yaitu gejala peristiwa alam dan sosial'". Berdasarkan pendapat para ahli diatas, dapat disimpulkan bahwa berpikir adalah suatu proses dialektis. Artinya, selama kita berpikir, pikiran kita mengadakan tanya jawab dengan pikiran kita, untuk dapat meletakkan hubungan-hubungan kita antara ketahuan kita, denga tepat dan benar. Pertanyaan itulah yang memberi arah kepada pikiran kita untuk mencapai tujuan.

Kreatif berasal dari bahasa inggris 'create'yang artinya menciptakan, sedangkan kreatif mengandung pengertian memiliki daya cipta, mampu merealisasikan ide-ide dan perasaanya sehingga tercipta sebuah komposisi dengan warna dan nuansa baru. Kecerdasan seseorang berpengaruh terhadap ide-ide kreatif yang dihasilkan dengan kata berarti ide kreatif bergantung pada kecerdasaan. Dalam kemampuan seseorang untuk dapat berhasil dalam kehidupannya antara lain ditentukan oleh keterampilan berpikirnya, terutama dalam upaya memecahkan masalahmasalah kehidupan yang dihadapinya. Menurut pendapat di atas, maka penulisdapat menyimpulkan bahwa berpikir akan memberikan solusi dari permasalah yang dihadapi oleh seseorang.

Berpikir kreatif adalah berpikir yang dapat menghubungkan atau melihat sesuatu dari sudut pandang baru yang mengembangkan ide-ide yang tidak biasa dan menghasilkan pemikiran 
ISSN. 2621-9832

JURNAL MathEdu (Mathematic Education Journal) http://journal.ipts.ac.id/index.php/MathEdu Vol. 4 No. 3 November 2021

yang baru yang memiliki ruang lingkup yang luas.Johnson dalam (Novi 2013) menyatakan "berpikir kreatif merupakan mencari kesempatan untuk mengubah sesuatu menjadi lebih baik.Susanto (2013:110) menyatakan "berpikir kreatif merupakan sebuah proses yang melibatkan unsur-unsur orisinalitas, kelancaran, fleksibilitas, dan elaborasi'”. Berdasarkan beberapa defenisi kemampuan berpikir kreatif dari para ahli, maka dapat disimpulkan bahwa berpikir kreatif adalah sebagai kemampuan untuk menghasilkan atau mengembangkan sesuatu yang baru. Yaitu sesuatu yang berbeda dari ide-ide yang dihasilkan kebanyakan orang dan berpikir kreatif memiliki kemampuan dan hasil berpikir yang berbeda satu sama lain.

Berdasarkan teori diatas, penulis menyusun indikator kemampuan berpikir kreatif sesuai dengan yang didefenisikan Munandar (1999), yaitu "a) keterampilan berpikir lancar (fluency), b) keterampilan berpikir luwes (flexibility), c) keterampilan berpikir orisinal (originality), d) keterampilan memerinci (elaboration)". Untuk lebih memahami indikator kemampuan berpikir kreatif, penulis akan membahas setiap indikator tersebut yaitu:

\section{Keterampilan berpikir lancar (fluency)}

Berpikir lancar adalah proses yang dilakukan individu dalam memecahkan suatu permasalahan dan menghasilkan ide baru secara lancar dalam suatu kegiatan. Dengan berpikir lancar kita dapat membangkitkan sebuah ide seperti dikatakan oleh Jamaris dalam (SriRejeki, Rahmatika dan Agus 2010) menyatakan "kelancaran (fluency)ialah kemampuan dalam memberikan jawaban atau mengemukakan pendapat atau ide-ide". Menurut Hudgiris dalam (SriRejeki, Rahmatika dan Agus 2017) "Dengan berpikir lancar kita dapat menyelesaikan soal dilihat dari banyaknya jawaban yang berbeda-beda".

Ciri-ciri berpikir lancar, yaitu mencetuskan banyak gagasan, jawaban, penyelesaian masalah atau pertanyaan, memberikan banyak cara atau saran untuk melakukan berbagai hal, selalu memikirkan lebih dari satu jawaban. Keterampilan ini ditunjukan oleh perilaku siswa, seperti: mengajukan banyak pertanyaan, menjawab dengan sejumlah jawaban jika ada pertanyaan, mempunyai banyak gagasan cara pemecahan suatu masalah, lancar dalam mengungkapkan gagasan-gagasannya, bekerja lebih cepat dan melakukan lebih banyak dari pada anak-anak lain, dapat dengan cepat melihat kesalahan atau kekurangan dari suatu objek atau situasi.Berdasarkan pendapat para ahli di atas, dapat disimpulkan bahwa berpikir lancar (fluency) adalah suatu kemampuan yang dapat menghasilkan banyak ide atau gagasan yang dengan cepat tanpa ragu sehingga dalam menjawab pertanyaan yang banyak akan terjawab dengan mudah.

\section{Keterampilan berpikir luwes (flexibility)}

Berpikir luwes adalah kemampuan berpikir secara luas, tidak terpokus pada satu cara saja. Menurut Jamaris dalam (SriRejeki, Rahmatika dan Agus 2010)"berpikir luwes (flexibility) merupakan berupa kemampuan untuk mengemukakan berbagai alternatif dan memecahkan masalah". Hudgiris dalam (SriRejeki, Rahmatika dan Agus 2017) menyatakan "keluwesan (flexibility) pada umumnya diukurdengan menghitung banyaknya kategori jawaban yang berbedabeda.

Ciri-ciri keterampilan berpikir luwes, yaitu: menghasilkan gagasan, jawaban atau pertanyaan yang lebih bervariasi, dapat melihat masalah dari sudut pandang yang berbeda-beda, mencari banyak alternatif atau arah yang berbeda-beda, mampu mengubah cara pendekatan atau cara pemikiran. Keterampilan ini ditunjukkan oleh perilaku siswa, seperti: memeriksa aneka ragam penggunaan yang tidak lazim terhadap suatu objek, memberi macam-macam penafsiran (interprestasi) terhadap suatu gambar, cerita atau masalah, menerapkan suatu konsep atau asas dengan cara yang berbeda-beda, memberikan pertimbangan terhadap situasi yang berbeda dari yang diberikan oleh orang lain, dalam membahas atau mendiskusikan situasi selalu mempunyai posisi yang berbeda atau bertentangan dari mayoritas kelompok, jika diberikan suatu masalah biasanya memikirkan macam-macam cara yang berbeda-beda unuk menyelesaikannya, menggolongkan hal-hal menurut pembagian (kategori) yang berbeda-beda,mampu mengubah arah berpikir secara spontan. Berdasarkan pendapat para ahli di atas, dapat disimpulkan bahwa berpikir luwes (flexibility) adalah suatu kemampuan dalam berpikir kreatif yang dapat menghasilkan produk, persepsi, ide atau gagasan, dan pertanyaan yang bervariasi, serta menghasilkan banyak macam pemikiran yang berbeda-beda. 
ISSN. 2621-9832

JURNAL MathEdu (Mathematic Education Journal) http://journal.ipts.ac.id/index.php/MathEdu

Vol. 4 No. 3 November 2021

\section{Keterampilan berpikir orisinal (originality)}

Keterampilan berpikir orisinal adalah kemampuan yang menghasilkan ide baru atau ide yang sebelumnya tidak ada. Ciri-ciri keterampilan orisinil, yaitu: mampu mengungkapkan hal yang baru dan unik, memikirkan cara yang tidak lazim, untuk mengungkapkan diri, mampu membuat kondisi yang tidak lazim dari bagian-bagian atau unsur-unsur. Keterampilan ini ditunjukkan oleh perilaku siswa, seperti: memikirkan masalah-masalah atau hal-hal yang tidak pernah terpikir oleh orang lain, mempertanyakan cara-cara yang lama dan berusaha memikirkan cara-cara yang baru, memilih asimetri dalam gambar atau membuat desain, memiliki cara berpikir yang lain dari yang lain, mencari pendekatan yang baru, setelah membaca atau mendengar gagasan-gagasan bekerja untuk menemukan penyelesaian yang baru.

\section{Keterampilan berpikir memerinci (elaboration)}

Keterampilan berpikir memerinci adalah keterampilan berpikir yang lebih terperinci, dapat merincikan sesuatu dengan jelas.Jamaris dalam (SriRejeki, Rahmatika dan Agus 2010) menyatakan "memerinci (elaboration)merupakan kemampuan untuk memperluas ide atau aspekaspek yang mungkin tidak terpikirkan atau terlihat oleh orang lain". Menurut Ramdani dalam (SriRejeki, Rahmatika dan Agus 2014) "berpikir memerinci artinya siswa mampu memperkaya dan mengembangkan gagasan orang lain".

Ciri-ciri keterampilan memerinci, yaitu: mampu memperkaya dan mengembangkan suatu gagasan atau produk, menambah atau memerinci secara detail dari suatu objek, gagasan atau situasi sehingga menjadi lebih menarik. Keterampilan ini ditunjukkan oleh perilaku siswa, seperti: mencari arti yang lebih mendalam terhadap jawaban atau pemecahan masalah dengan melakukan langkah-langkah yang terperinci, mengembangkan atau memperkaya gagasan orang lain, mencoba atau menguji secara detail untuk melihat arah yang akan ditempuh, mempunyai rasa keindahan yang kuat sehingga tidak puas dengan penampilan yang kosong dan sederhana, membuat garisgaris, warna-warna dan detail-detail (bagian-bagian) terhadap gambarnya sendiri atau gambar orang lain.Berdasarkan uraian di atas, maka dapat disimpulkan bahwa berpikir kratif dengan keterampilan memerinci adalah mengembangkan dan menumbuhkan suatu idea atau gagasan serta memperluas gagasan tersebut.

Sebagaimana yang dikemukakan Munandar diatas, bahwa pemikiran kreatif menuntut kelancaran, keluwesan, dan kemandirian dalam berpikir serta mengembangkan suatu gagasan (elaborasi), maka dapat mengajukan pertanyaan-pertanyaan yang baik termasuk pula dalam berpikir kreatif. Kelancaran berpikir disini dimaksudkan dengan keterampilan mencetuskan banyak gagasan, jawaban, penyelesaian masalah atau pertanyaan, memberikan banyak cara atau saran untuk melakukan berbagai hal dengan selalu memikirkan lebih dari satu jawaban.

\section{METODE PENELITIAN}

Metode penelitian merupakan salah satu proses yang dibutuhkan untuk menyelesaikan suatu penelitian. Rangkuti (2016:13) menyatakan "Metode penelitian merupakan suatu cara ilmiah untuk mendapatkan data yang valid dengan tujuan dapat ditemukan, dikembangkan, atau dibuktikan, suatu pengetahuan tertentu sehingga pada gilirannya dapat digunakan untuk memahami, memecahkan dan mengantisipasi masalah dalam bidang tertentu'. Sugiyono (2011:3) menyatakan "Metode penelitian dapat diartikan sebagai cara ilmiah untuk mendapatkan data yang valid dengan tujuan dan kegunaan tertentu". Kemudian Noor (SriRejeki, Rahmatika dan Agus 2019) menyatakan "Metode penelitian merupakan cara melakukan sesuatu menurut aturan tertentu, suatu proses yang sistematik berdasarkan prinsip dan teknik ilmiah yang dipakai oleh disiplin ilmu untuk tujuan tertentu'. Berdasarkan pendapat para ahli di atas, penulis menyimpulkan bahwa metode penelitian merupakan cara atau prosedur yang sistematis dan dapat dipakai untuk mendapatkan data yang valid untuk kegunaan tertentu. Dalam penelitian ini, penulis menggunakan metode penelitian kualitatif. Menurut Sugiyono dalam (Nurhazanah, Rahmatika, Nunik 2014) metode penelitian kualitatif merupakan metode yang pada dasarnya merupakan cara ilmiah untuk mendapatkan data dengan tujuan dan kegunaan tertentu.

Aktivitas penelitian tidak akan terlepas dari keberadaan data yang merupakan bahan baku informasiuntuk memberikan gambaran spesifik mengenai objek penelitian. Menurut Trianto (2011:279)"data adalah fakta empiris yang dikumpulkan oleh peneliti untuk kepentingan memecahkan masalah atau menjawab pertanyaan penelitian". Data penelitian dapat berasal dari berbagai sumber yang dikumpulkan dengan menggunakan berbagai teknik selama kegiatan 
penelitian berlangsung. Berdasarkan pendapat Trianto (2011:279) penulis dapat menyimpulkan bahwa, data adalah data yang dikumpulkan untuk menjawab pertanyaan selama kegiatan penelitian berlangsung.

Teknik pengumpulan data merupakan cara yang digunakan peneliti untuk mendapatkan data dalam suatu penelitian. Menurut Sugiyono (2012) bahwa pengumpulan data dapat diperoleh dari hasil observasi, wawancara, dokumentasi, dan gabungan atau triangulasi. Pada penelitian ini peneliti menggunakan teknik pengumpulan data dengan cara wawancara, tes, dan dokumentasi.

Tabel 1. Rubrik Penilaian Kemampuan Berpikir Kreatif Siswa

\begin{tabular}{|c|c|c|c|}
\hline No & Aspek Berpikir Kreatif & Indikator & Skor \\
\hline \multirow[t]{5}{*}{1} & \multirow[t]{5}{*}{ Berpikir lancar } & Tidak menulis yang diketahui dan ditanya & 0 \\
\hline & & $\begin{array}{l}\text { Menulis yag diketahui dan yang ditanya dengan tidak } \\
\text { tepat }\end{array}$ & 1 \\
\hline & & $\begin{array}{l}\text { Menulis yang diketahui saja dengan tepat atau yang } \\
\text { ditanyakan saja dengan tepat }\end{array}$ & 2 \\
\hline & & $\begin{array}{l}\text { Menulis yang diketahui dari soal dengan tepat dan } \\
\text { lengkap tetapi kurang lengkap }\end{array}$ & 3 \\
\hline & & $\begin{array}{l}\text { Menulis yang diketahui dan ditanya dari soal dengan } \\
\text { tepat dan lengkap }\end{array}$ & 4 \\
\hline \multirow[t]{5}{*}{2} & \multirow[t]{5}{*}{ Fleksibel } & $\begin{array}{l}\text { Tidak menjawab atau memberikan jawaban dengan } \\
\text { satu cara atau lebih tetapi sebuah salah }\end{array}$ & 0 \\
\hline & & $\begin{array}{l}\text { Memberikan jawaban hanya satu cara tetapi } \\
\text { memberikan jawaban yang salah }\end{array}$ & 1 \\
\hline & & $\begin{array}{l}\text { Memberikan jawaban jawaban dengan satu cara,proses } \\
\text { perhitungan dan hasilnya benar }\end{array}$ & 2 \\
\hline & & $\begin{array}{l}\text { Memberikan jawaban lebih dari satu cara (beragam) } \\
\text { tetapi hasil nya ada yang salah karena terdapat } \\
\text { kekeliruan dalam proses perhitungan }\end{array}$ & 3 \\
\hline & & $\begin{array}{l}\text { Memberikan jawaban lebih dari satu cara } \\
\text { (beragam),proses perhitungan dan hasil nya benar }\end{array}$ & 4 \\
\hline \multirow[t]{5}{*}{3} & \multirow[t]{5}{*}{ Original } & $\begin{array}{l}\text { Tidak menjawab atau memberikan jawaban pemikiran } \\
\text { sendiri bernilai salah }\end{array}$ & 0 \\
\hline & & $\begin{array}{l}\text { Memberikan jawaban yang biasa diberikan orang lain } \\
\text { tetapi langkah dan selesaian bernilai salah }\end{array}$ & 1 \\
\hline & & $\begin{array}{l}\text { Memberikan jawaban yang biasa diberikan orang lain } \\
\text { tetapi langkah dan selesaian bernilai benar. }\end{array}$ & 2 \\
\hline & & $\begin{array}{l}\text { Memberikan jawaban pemikiran sendiri (yang tidak } \\
\text { biasa/jarang diberikan kepada orang lain) namun } \\
\text { terdapat kekurangan karena perhitungan yang salah. }\end{array}$ & 3 \\
\hline & & $\begin{array}{l}\text { Memberikan jawaban pemikiran sendiri (yang tidak } \\
\text { biasa/jarang diberikan orang lain) dan jawaban bernilai } \\
\text { benar. }\end{array}$ & 4 \\
\hline \multirow[t]{6}{*}{4} & \multirow[t]{6}{*}{ Elaborasi } & Tidak menjawab atau memberikan jawaban yang salah & 0 \\
\hline & & $\begin{array}{l}\text { Terdapat kesalahan dalam jawaban dan tidak disertai } \\
\text { dengan perincian }\end{array}$ & 1 \\
\hline & & $\begin{array}{l}\text { Terdapat kesalahan dalam jawaban dalam tapi disertai } \\
\text { dengan perincian yang kurang detail }\end{array}$ & 2 \\
\hline & & $\begin{array}{l}\text { Terdapat kesalahan dalam jawaban tetapi disertai } \\
\text { dengan perincian yang rinci }\end{array}$ & 3 \\
\hline & & Memberikan jawaban yang benar dan rinci & 4 \\
\hline & & Total Skor & 16 \\
\hline
\end{tabular}

Keabsahan data merupakan konsep paling penting dalam sebuah penelitian kualitatif. Melalui keabsahan data kepercayaan penelitian kualitatif dapat tercapai. Dalam penelitian ini, ada beberapa teknik pemeriksaan keabsahan data yang berupa: 
ISSN. 2621-9832

JURNAL MathEdu (Mathematic Education Journal) http://journal.ipts.ac.id/index.php/MathEdu

Vol. 4 No. 3 November 2021

\section{Pepanjangan pengamatan}

Hal ini berarti peneliti kembali ke lapangan, melakukan pengamatan dan wawancara dengan sumber data yang pernah ditemui maupun sumber data yang baru. Hal ini bertujuan untuk menumbuhkan keakraban antara peneliti dan narasumber sehingga tidak ada informasi yang disembunyikan lagi.

\section{Peningkatan ketekunan}

Peneliti bermaksud untuk menemukan ciri-ciri dan unsur-unsur dalam situasi yang sangat relevan dengan persoalan atau isu yang sedang dicari dan kemudian memusat diri pada hal-hal tersebut secara inci. Peneliti mengadakan penelitian dengan teliti dan terinci secara berkesinambungan terhadap faktor-faktor yang menonjol sampai pada suatu saat semua faktor yang telah sudah dipahami dengan cara yang biasa.

3. Triangulasi

Triangulasi adalah teknik pemeriksaan keabsahan data yang memanfaatkan sesuatu pada yang lain di luar data itu untuk keperluan pengecekan atau pembanding terhadap data tersebut. Triangulasi dalam pengujian kredibilitas ini diartikan sebagai pengecekan data dari berbagai cara dan waktu. Terdapat triangulasi sumber, triangulasi teknik pengumpulan data dan waktu. Triangulasi sumber dilakukan dengan cara mengecek data yang telah diperoleh melalui beberapa sumber, triangulasi teknik dilakukan dengan cara mengecek data kepada sumber yang sama dengan teknik yang berbeda, dan triangulasi waktu dilakukan dengan cara melakukan pengecekan dengan wawancara, observasi atau teknik lain dalam waktu dan situasi yang berbeda.

4. Menggunakan bahan referensi

Bahan referensi disini adalah adanya pendukung untuk membuktikan data yang telah ditemukan oleh peneliti. Contoh, data hasil wawancara perlu didukung dengan adanya foto-foto wawancara sangat diperlukan untuk mendukung kredibilitas data yang telah ditemukan peneliti.

5. Membercheck

Membercheck adalah proses pengecekan data yang diperoleh peneliti kepada informan. Tujuan membercheck adalah untuk mengetahui seberapa jauh data yang diperoleh sesuai dengan apa yang diberikan oleh informan.

Berdasarkan teknik pemeriksaan keabsahan data, peneliti menggunakan teknik triangulasi. Adapun triangulasi teori yaitu pengumpulan data berbagai teori yang berlainan untuk memastikan bahwa data yang dikumpul sudah memenuhi syarat. Menurut sugiyono dalam Nurlinta (2020) Menyatakan bahwa "triangulasi dengan sumber berarti membandingkan dan mengecek balik derajat kepercayaan suatu informasi yang diperoleh melalui waktu dan alat yang berbeda dalam penelitian kualitatif'.

Analisis data yang digunakan dalam penelitian kualitatif adalah logika ilmiah. Proses data ilmiah dimulai dengan menelah seluruh data yang tersedia dari berbagai sumber, yaitu dari wawancara, observasi, yang sudah dituliskan dalam catatan lapangan, dokumentasi resmi, foto dan sebagainya. Menurut Neong Muhadjir (1998:104) "analisis data merupakan sebagai upaya mencari dan menata secara sistematis catatan hasil observasi, wawancara dan lainnya untuk meningkatkan pemahaman peneliti tentang kasus yang diteliti dan menyajikan sebagai temuan bagi orang lain. Sedangkan untuk meningkatkan pemahaman tersebut analisis perlu dilanjutkan dengan berupa mencari makna". Teknik analisis data dilakukan dengan dua tahap yaitu analisis sebelum lapangan dan analisis selama dilapangan yang terdiri dari reduksi data, penyajian data, dan penyimpulan.

\section{HASIL DAN PEMBAHASAN}

Hasil penelitian yang telah di analisis peneliti ditemukan bahwa siswa yang memiliki kemampuan tinggi dalam tahap perencanaan, siswa dapaat menjelaskan apa yang diketahui dan apa yang ditanyakan. Siswa juga mampu memahami rumus apa yang dibutuhkan dan pengetahuan apa yang dibutuhkan untuk menyelesaikan permasalahan soal. Tetapi siswa tidak dapat memenuhi satu indikator yaitu berpikir luwes (flexibilty), siswa tidak dapat memberikan langkah dengan beberapa cara yang berbeda. Hal ini menunjukkan bahwa siswa yang berkemampuan tinggi tidak bisa memenuhi satu indikator berpikir kreatif.

Hasil penelitian pada siswa yang berkemampuan sedang. siswa mampu menuliskan apa yang diketahui dan apa yang ditanyakan pada soal. Siswa mampu menuliskan langkah-langkah walaupun dengan satu cara. Tetapi ada siswa yang lupa menuliskan hasil kesimpulan dari soal tersebut. Hasil penelitian pada siswa yang rendah. kemampuan siswa rendah dalam memahami 
ISSN. 2621-9832

JURNAL MathEdu (Mathematic Education Journal) http://journal.ipts.ac.id/index.php/MathEdu Vol. 4 No. 3 November 2021

masalah, membuat langkah-langkah dalam mengerjakan soal, memberikan jawaban dari hasil pemikiran sendiri, serta membuat hasil jawaban secara rinci(detail).

Hasil penelitian wawancara dengan guru matematika yaitu kemampuan siswa dalam menyelesaikan soal matematika masih rendah. Karena sebagian siswa masih harus diajari dalam mengerjakan soal. Terkadang siswa merasa bingung dalam mengerjakan soal. Terkadang siswa hanya diam saja ketika guru sedang memberikan pertanyaan. Siswa juga mengalami kesulitan untuk menjawab soal yang diberikan oleh guru, siswa bingung menuliskan apa yang diketahui dan ditanya dan menggunakan rumus tersebut, apalagi soal dalam bentuk cerita.

\section{KESIMPULAN}

Berdasarkan hasil temuan dari masalah diperoleh analisis kemampuan berpikir kreatif siswa dalam menyelesaikan soal matematika kelas X TKJ SMK Swasta Haarapan sebagai berikut:

1. Siswa yang memiliki kemampuan matematika tinggi memiliki tingkat kemampuan yang sangat baik. Karena mampu memahami masalah, membuat langkah walaupun dengan satu cara yang berbeda. Mengerjakan soal dari pemikiran sendiri dan membuat hasil jawaban secara rinci. Sehingga dapat disimpulkan bahwa siswa yang memiliki tingkat kemampuan berpikir kreatif yang sangat baik yaitu memiliki keterampilan berpikir lancar, keluasan, keaslian, dan memerinci. Sehinggga berpikir kreatif siswa dalam Barisan dan Deret dapat diterapkan.

2. Siswa yang memiliki kemampuan yang sedang memiliki tingkat kemampuan berpikir kreatif yang baik tetapi belum sepenuhnya menguasi dalam membuat langkah-langkah dalam menyelesikan soal dan hasil kesimpulan dari soal tersebut. Sehingga kemampuan berpikir kreatif dalam penerapannya akan berkurang terutama dalam materi Barisan dan Deret.

3. Siswa yang memiliki kemampuan matematika rendah memiliki tingkat kemampuan berpikir kreatif yang kurang baik karena tidak mampu memahami masalah, membuat langkahlangkah dalam menyelesaikan soal, kemampuan berpikir dari pemikiran sendiri serta membuat hasil jawaban secara rinci. Sehingga dapat disimpulkan bahwa siswa yang tidak memiliki tingkat kemampuan berpikir kreatif yang kurang baik yaitu tidak memiliki keterampilan berpikir lancar, keluasan, keaslian dan memerinci. Sehingga kemampuan berpikir kreatif siswa dalam Barisan dan Deret tidak dapat diterapkan.

\section{Implikasi}

Berdasarkan kesimpulan di atas, maka dapat ditarik kesimpulan bahwa kemampuan berpikir kreatif siswa dalam menyelesaikan soal matematika pada materi Barisan dan Deret cukup baik. Karena dari analisis jawaban soal tes kemampuan berpikir kreatif siswa pada materi Barisan dan Deret ada beberapa siswa yang mampu menerapkan dengan baik tetapi ada juga yang tidak mampu menerapkan berpikir kreatif siswa dalam materi Barisan dan Deret. Menyelesaikan Barisan dan Deret sejalan dengan indikator kemampuan berpikir kreatif siswa. Oleh karena itu pentingnya kesadaran diri untuk memahami kemampuan berpikir kreatif siswa agar penerapan pada materi Barisan dan Deret dapat berjalan dengan baik. Memakai indikator berpikir kreatif dalam menyelesaikan soal materi Barisan dan Deret akan lebih berstruktur dan terarah.

\section{Saran}

Berdasarkan kesimpulan di atas, dapat dikemukakan saran-saran sebagai berikut:

1. Bagi siswa, diharapkan untuk lebih giat lagi dalam memperdalam materi pembelajaraan disekolah. Siswa harus lebih konsentrasi lagi dan lebih aktif dalam proses pembelajaran serta mampu menemukan ide-ide baru dengan belajar sendiri dan tidak tergantung pada pelajaran yang diberikan gurunya.

2. Kepada orangtua, diharapkan lebih meningkatkan kesadaran yang tinggi terhadap pendidikan anak,sehingga orangtua murid bersedia melengkapi fasilitas-fasilitas belajar siswa berupa perlengkapan sekolah agar siswa belajar dengan baik.

3. Bagi kepala sekolah, diharapkan dapat mendorong dan membina para guru untuk melaksanakan proses pembelajaran dengan baik dengan memberikan masukan kepada guru kelasnya supaya meningkatkan kemampuan mengajar khususnya pada pelajaran matematika.

4. Bagi penulis, agar penelitian ini bisa dijadikan referensi untuk menambah pengalaman dan wawasan dengan baik dalam bidang pendidikan. 


\section{REFERENSI}

Ardiana, Nunik, dkk. 2020. Analisis hasil belajar matematika siswa ditinjau dari gaya belajar siswa di SMP-IT Bunayya Padangsidimpuan. Jurnal MathEdu Vol. 3. No . 3 November 2020.

Arikunto, Suharsimi. 2009. Manajemen Penelitian. Jakarta: Rineka Cipta 2009.

Elindra, Rahmatika. 2017. Pengaruh Penggunaan Model Pembelajaran Creative Problem Solving (CPS) Terhadap Kemampuan Berpikir Kreatif Matematika Mahasiswa STKIP Tapanuli Selatan. Jurnal Penelitian Dan Pembelajaran MIPA, 2017.

Elindra, Rahmatika, dkk. 2020. Efektivitas Penggunaan Model Pembelajaran Kontekstual Terhadap Kemampuan Berpikir Kreatif Matematis Siswa Di SMP Negeri 9 Padangsidimpuan. Jurnal MathEduVol. 3. No. 3 November 2020. ISSN. 2621-9832.

Febrianti, Yeyen, dkk. 2016. Analisis Kemampuan Berpikir Kreatif Peserta Didik Dengan Memanfaatkan Lingkungan Pada Mata Pelajaraan Ekonomi Di SMA Negeri 6 Palembang. Jurnal ProfitVol. 3, No. 1, Mei 2016.

Harahap, Muhammad Syahril, dkk. 2020. Efektifitas Model Pembelajaran Kooperatif Tipe Student Teams Achievenment Division (Stad) Terhadap Kemampuan Pemecahan Masalah Matematis Siswa SMA Negeri 1 Angkola Selatan. Jurnal MathEdu Vol. 3. No. 1 Maret 2020

Marliani, Novi. 2015. Peningkatan Kemampuan Berpikir Kreatif Matematis Siswa Melalui Model Pembelajaran Missouri MathematicsProject (MPP). Jurnal Formatif 5 (1): 14-15. ISSN. 2088-351x.

Nurmasari, Nina. 2014. Analisis Berpikir Kreatif Siswa Dalam Menyelesaikan Masalah Matematika Pada Materi Peluang Ditinjau Dari Gender Siswa Kelas XI IPA SMA Negeri 1 Kota Banjarbaru Kalimantan Selatan. Jurnal Elektronik Pembelajaran Matematika Vol. 2, No. 4, hal 351-358, Juni 2014. ISSN. 2339-1685.

Ramadhani, Dini dan Nuryanis. 2017. Analisis Kemampuan Berpikir Kreatif Matematis Siswa SD Dalam Menyelesaikan Open-Ended Problem. Jurnal JPSD Vol. 4 No. 2. ISSN 23563869.

Sondak, Sandi Hesti, dkk. 2019. Faktor-Faktor Loyalitas Pegawai Di Dinas Pendidikan Daerah Provinsi Sulawesi Utara. Jurnal EMBAVol. 7 No. 1 Januari 2019, Hal. 671-680.

Sugiyono. 2016. Metode Penelitian Kombinasi (Mixed Methods). Bandung No. 84.

Sugiyono. 2014. Metode Penelitian Kombinasi (Mixed Methods). No. 84 Bandung

Sukmadinata, Nana Syaodih. 2010. Metode Penelitian Pendidikan. No. 40, Bandung 40252.

Susanto, Ahmad. 2013. Teori Belajar Pembelajaran Di Sekolah Dasar.Jakarta 13220. Hal 6.

Trianto. 2011. Pengantar Penelitian Pendidikan Bagi Pengembangan Profesi Pendidikan Dan Tenaga Pendidikan. Jakarta: Kencana 2011.

Widiastuti, Yeni dan Putri,Ratu Ilma Indra. 2018. Kemampuan berpikir kreatif siswa pda pembelajaran operasi pecahan menggunakan pendekatan Open-Ended. Jurnal Pendidikan MatematikaVol. 12, No. 2, Juli 2018. ISSN. 1978-1040. 